YEARBOOK

of ANTITRUST

and REGULATORY

STUDIES

www.yars.wz.uw.edu.pl
Peer-reviewed scientific periodical, focusing on legal and economic issues of antitrust and regulation. Creative Commons Attribution-No Derivative Works 3.0 Poland License.

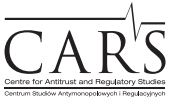

Centre for Antitrust and Regulatory Studies, University of Warsaw, Faculty of Management www.cars.wZ.uw.edu.pl

\title{
Compensatory Collective Redress: Will It Be Part of Private Enforcement of Competition Law in CEE Countries?
}

\author{
by
}

Anna Piszcz*

\section{CONTENTS}

I. Introductory remarks

II. CEE countries - the state of play

III. Terminological preliminaries

IV. Compensatory collective redress in Bulgaria

V. Compensatory collective redress in Lithuania

VI. Compensatory collective redress in Poland

VII. Compensatory collective redress in Slovenia (draft legislation)

VIII. Questions to be addressed by CEE countries

IX. Is there strength in numbers? Conclusions

\section{Abstract}

The article aims to compare and evaluate solutions with regard to compensatory collective redress existing in CEE countries. The author will attempt to illuminate obstacles and challenges to using collective redress as an avenue for antitrust enforcement in CEE countries, as well as possible advantages of the scrutinised legal frameworks. Besides focusing on national provisions, the article will draw on provisions of the Damages Directive and the Commission's Recommendation on collective redress mechanisms. It will open up the field for de lege ferenda proposals also.

* Dr. Hab., Professor at the University of Białystok, Faculty of Law, Department of Public Economic Law; legal advisor; piszcz@uwb.edu.pl. Article received: 16.07.2017; accepted: 29.09.2017. 


\section{Résumé}

Larticle vise à comparer et évaluer les solutions en matière de recours collectifs en indemnisation existant dans les pays d'Europe centrale et orientale («PECO»). Lauteur a pour le but de mettre en lumière les obstacles et les défis liés à l'utilisation des recours collectifs comme moyen d'application privée du droit de la concurrence dans les PECO, ainsi que les avantages éventuels des cadres juridiques examinés. Larticle va se concentrer non seulement sur les dispositions nationales, mais aussi va s'inspirer des dispositions de la Directive Dommages et de la Recommandation de la Commission portant sur les mécanismes de recours collectifs. Cela ouvrira également le terrain pour des propositions de lege ferenda.

Key words: compensatory collective redress; private enforcement; competition law; opt-in model; opt-out model; mixed model; group actions; representative actions.

JEL: K21

\section{Introductory remarks}

The Damages Directive ${ }^{1}$ does not require Member States to introduce collective redress mechanisms for the enforcement of Articles 101 and 102 TFEU, albeit they are free to do so. Recital 13 sentence 2 of the Preamble to the Directive declares: 'This Directive should not require Member States to introduce collective redress mechanisms for the enforcement of Articles 101 and 102 TFEU'. This seems to contradict the emphasis put by the European Commission on collective redress in the Recommendation on common principles for injunctive and compensatory collective redress mechanisms in the Member States concerning violations of rights granted under Union Law (hereinafter, Commission's Recommendation). ${ }^{2}$ In its Preamble, Recital 7 lists competition and consumer protection alongside environmental protection, protection of personal data, financial services legislation and investor protection as areas where supplementary private enforcement of rights granted under EU law in the form of collective redress is of value. It is worth noting that the earlier quoted provision of the Directive was already present in the draft Directive circulated at the same time as the publication

1 Directive 2014/104/EU of the European Parliament and of the Council of 26.11.2014 on certain rules governing actions for damages under national law for infringements of the competition law provisions of the Member States and of the European Union, OJ L 349, 05.12.2014, p. 1 .

2 2013/396/EU, OJ L 201, 26.07.2013, p. 60. 
of the Commission's Recommendation. It seems that the Commission drove a wedge between collective redress and private enforcement of competition law, with some Member States likely to oppose the voluntary introduction of legal frameworks for compensatory collective redress as part of private enforcement of competition law.

The system of private enforcement of competition law is made up of a variety of remedies, including injunctive relief (where the plaintiff requests the court to order the infringer to stop the violation and/or remove its effects), compensatory relief (damages), declaratory relief (the declaration of invalidity of an agreement, decision of an association of undertakings or practice) and other remedies (S. Peyer mentions separately also interim remedies; see Peyer, 2012, p. 350). There seems to be more than only injunctive collective redress and compensatory collective redress referred to in the Commission's Recommendation. However, since the scope of the Damages Directive includes claims for damages, this article refers only to compensatory relief and, thus, only to compensatory collective redress, as part of private enforcement of competition law.

This paper will focus on possible obstacles and challenges to using collective redress as an avenue for antitrust enforcement in CEE countries, as well as on possible advantages of the scrutinised legal frameworks. In addition to the presentation of both the drawbacks and the strong points of the relevant legal provisions, references to the Commission's Recommendation on collective redress and the Damages Directive will be made. The decision-makers' attitudes towards collective redress, in particular during the process of the implementation of the Directive, will be shown. The paper will debate the question of what changes might be advisable in collective redress in order for it to function in the field of antitrust enforcement.

\section{CEE countries - the state of play}

A developed legal basis for compensatory collective private enforcement of competition law exists in three Central and Eastern European (CEE) Member States of the EU, namely Bulgaria (from 01.03.2008), Poland (from 19.07.2010) and Lithuania (from 01.01.2015); however, none of them has a record of successful collective actions for antitrust damages (Petrov, 2017, p. 49-51; Piszcz and Wolski, 2017, p. 229; Mikelènas and Zaščiurinskaitè, 2017, p. 199). In Romania, a legal basis for collective actions of those who claim to have suffered harm does not exist; only consumer associations are entitled to bring representative actions on behalf of consumers. So far, however not a single 
such action has been brought by such associations before Romanian courts (Mircea, 2017, p. 244-245). Croatia and Hungary have introduced collective redress mechanisms but they cannot be used to pursue claims for damages in competition law cases (Butorac Malnar, 2017, p. 58; Miskolczi Bodnár, 2017, p. 150-152). In Slovenia, representative actions filed by organizations for the protection of consumers are not particularly relevant for collective private antitrust enforcement (Vlahek and Podobnik, 2017, p. 284-285; Vlahek, 2016, p. 380-381, Vlahek, 2016a, p. 565). In Slovakia, the legal standing of consumer associations in representative actions has been narrowed down (accidentally?), so that they are now unable to pursue claims for damages in competition law cases (Blažo, 2017, p. 248-249).

It needs adding that the legal basis for compensatory collective private enforcement of competition law is going to be introduced in Slovenia (Vlahek and Podobnik, 2017, p. 289-290). Moreover, the Polish legal framework has been amended as of 1 June 2017, although not on the occasion of the implementation of the Damages Directive. When studied in the context of the Commission's Recommendation, the amendments seem to have been introduced in order to remove the drawbacks of the pre-existing legal framework identified in practice, rather than to implement the Commission's Recommendation. However, at some point in the legislative works, the Polish drafters noted that the amendments are justified in the light of the Commission's Recommendation. ${ }^{3}$

In other CEE countries, no clear signs that something fundamental in collective redress legislation (with regard to collective private enforcement of competition law) is going to be changed can be seen. In Estonia, a national debate on whether or not collective actions should be regulated has not provided a clear answer but, instead, revealed controversy on whether collective actions would be compliant with the Estonian constitution (PärnLee, 2017, p. 123).

Academics based in universities in CEE countries believe that collective redress mechanisms are needed in order to stimulate claimants with relatively small claims, for example consumers and small undertakings, and/or that the lack thereof is going to undermine the efficiency of antitrust damages (Butorac Malnar, 2017, p. 82; Mircea, 2017, p. 245; Pärn-Lee, 2017, p. 123; Blažo, 2017, p. 260; Petr, 2017, p. 107).

CEE countries face the dilemma between having a system of private antitrust enforcement with collective redress and a system without it. If one takes into account that collective redress may be based on the opt-in principle or on the

3 Explanatory Notes to the draft Amending Act. In Polish available at: http://orka.sejm.gov. pl/Druki8ka.nsf/0/B9D80E83748EE247C125809D004C3CB5/\%24File/1185-uzasadnienie.docx. All Internet references in this article were last visited on 27.06.2017. 
opt-out principle, procedural schemes for collective redress can be separated into two basic categories: the opt-in model and the opt-out model. In opt-in systems, any person that wants to participate in a collective action needs to affirmatively express her/his consent to be a party to the collective proceedings. The Commission's Recommendation advocates for an opt-in mechanism for compensatory collective redress (para. 21 sentence 1). In opt-out systems, a person shall participate in a collective action unless $\mathrm{s} /$ he effectively expresses the intention of not being represented by the group claimant. In practice, a mixed system (bi-model/hybrid system) can also be distinguished. CEE countries may, therefore, be considered even closer to facing a 'trilemma' than a dilemma (whether to introduce the model recommended by the Commission, to go with a different model, or not to introduce collective private enforcement of competition law at all). Opt-in systems of collective redress are present in Poland, Lithuania and also Romania with its limited collective redress mechanism (Piszcz, 2014, p. 373; Mikelènas and Zaščiurinskaité, 2017, p. 198-199; Stoica, Ion and Bercaru, 2015, p. 334). The Bulgarian system is also classified as an opt-in system (Petrov, 2017, p. 49), even though it may be considered closer to a mixed system.

This relative homogeneity may be found interesting against the background of the entire EU, where several countries adopted models different from the opt-in model. According to a comparative study of 2016 by M. Gac, Portugal, the Netherlands and England have the opt-out mechanism, while Denmark proposed a mixed system (Gac, 2016, p. 153). Outside of EU but still in Europe, Norway has a mixed system (for more see Ervo, 2016, p. 187-188).

Even more interestingly, the system which is going to be introduced in Slovenia is designed as a mixed system in which both opt-in or opt-out schemes shall be available to the courts (Vlahek and Podobnik, 2017, p. 290).

A collective redress mechanism is a procedural mechanism that traditionally has belonged to legal and court cultures completely different to CEE cultures. When it was introduced in Bulgaria in 2008, Poland in 2010 and Lithuania in 2015, with it came several important procedural phenomena, such as ensuring that the initiation of collective actions is well publicised, standardisation of claims or contingency fees.

\section{Terminological preliminaries}

Both the Damages Directive and the Commission's Recommendation use the phrase 'collective redress mechanisms'. As for CEE countries, first, some tend to use different terminology to describe their procedural schemes for 
collective redress mechanisms. Second, the American phrase 'class action' has never taken hold of these countries.

In Bulgaria, the Civil Procedure Code adopts the terminology of a 'колективен иск' (collective claim), as does Slovenia in its draft Act on Collective Actions where the phrase 'kolektivna tožba' (collective action) is used.

Interestingly, and in contrast to the above, the procedural scheme for collective redress present in Poland is called a 'postępowanie grupowe' (group proceedings), even though this Polish genre includes also proceedings conducted as a result of representative actions. The above terminology refers to an attribute of the claimant in question, that is, being a group. The collective action can be brought jointly by those who claim to have suffered harm. The criteria of a group are set out in statutory provisions. Hence, it may be clearly stated whether or not those who claim to have suffered harm are a group.

Similarly, Lithuania uses the terminology of a 'grupinis ieškinys' (group action) for its collective redress actions. However, this term does not relate to some representative actions. The latter are governed by legal provisions other than chapter 24-1 of the Civil Procedure Code (see below) and may be brought by consumer protection institutions or public consumer organisations; however, these entities cannot claim damages.

In the context of the present paper, group actions and representative actions shall be included under the umbrella term of 'collective actions'. A collective action means, where appearing in this article, the same as that interpreted from Section 3(a) of the Commission's Recommendation. Accordingly, 'collective redress' is a legal mechanism that ensures a possibility to claim a remedy collectively by two or more natural or legal persons or by an entity entitled to bring a representative action. Naturally, a 'collective action' means an action which is brought collectively by two or more natural or legal persons or by an entity entitled to bring a representative action. Furthermore, the genre of 'compensatory collective redress' (an expression introduced into Section 3(a) (ii) of the Commission's Recommendation) includes legal mechanisms that ensure a possibility to claim compensation collectively by two or more natural or legal persons claiming to have been harmed in a 'mass harm' situation, or by an entity entitled to bring a representative action. Collective redress should be considered broader than the term 'collective action' so as to include alternative methods of dispute resolution as well as recourse to the civil courts. 


\section{Compensatory collective redress in Bulgaria}

Bulgaria was the first country in Central and Eastern Europe to have a developed collective action procedure. Provisions on collective redress were included in the new Civil Procedure Code (chapter thirty three titled: 'Procedure on collective claims'), ${ }^{4}$ which came into force on 1 March 2008. Collective protection is afforded by a range of remedies. Compensatory collective redress is only one of them; it is provided for in Article 379(3) of the Code (additionally, Article 385).

Bulgarian law does not have a provision for a specialist court or tribunal to deal only with private enforcement of competition law, including its collective private enforcement. Collective claims may be brought before the regional (provincial) court (окръжен съд) as a court of first instance (Article 380(1) of the Code). There are 30 regional courts in Bulgaria. Regarding court registration fees, general rules for court fees apply - meaning that $4 \%$ of the value for which an award is sought must be paid upon the claim submission, which is considered a high initial requirement (Petrov, 2017, p. 50).

The rules impose two preconditions upon taking collective proceedings. First, there needs to be more than one potential claimant. There must be a group of persons to be represented (either by a member of the group or by an organisation responsible for the protection of injured persons or for the protection against a given type of infringements), even if the group is as small as two since, according to Article 379 of the Code, collective actions are brought 'on behalf of all injured persons'. ${ }^{5}$ There are no other threshold requirements with respect to standing. Second, the represented group of persons must be harmed by one and the same infringement and, due to the nature of the violation, the circle of such persons cannot be determined accurately but it is identifiable. Either institutional actors or private applicants may seek remedies (Article 379 of the Code).

The deficiencies of Bulgarian collective proceedings can be found already in their first stages. Due to the lack of clarity on the actual number of injured persons, it is often impossible to calculate precisely the claim value, which results in prolonged deliberations on preliminary issues (Petrov, 2017, p. 50). In the first stages of the proceedings, the court examines also the ability of the plaintiff(s) to protect the collective interest of the group represented 'genuinely and in good faith', and to bear the burdens in connection with the case, including the costs (Article 381(1) of the Code). This part of the

${ }^{4}$ See Articles 379-388 of the Code. Available in English at: https://www.lexadin.nl/wlg/legis/ nofr/eur/lxwebul.htm.

5 All emphases added by the author. 
proceedings may be seen as the certification of the 'competency' of the plaintiff or the prequalification, since the admissibility of a collective action is dependent on the decision of the court and there is a risk of a refusal of certification by an appealable decision (see also Piszcz, 2014, p. 363). After the admission of the collective action, the court hears the parties at a public session, investigating the circumstances that determine the group of injured persons, and an appropriate way to publicise the action (Article 382(1) of the Code). In an appealable interlocutory decision, the court determines: a way to publicise the action; the number of announcements to be made as well as through which media and for how long shall the relevant information be made public; and when injured persons may express their intention of joining the group or the intention of not being represented by the group claimant (Article 382(2)-(3) of the Code). Ensuring publicity is considered to be a 'substantial, if not insurmountable, barriers for litigation', since courts normally make it quite expensive (Petrov, 2017, p. 50). For example, courts may select announcements to be made in TV, radio or major national printed media as a way to publicise the action and to require dozens of spots and/or publications therein (ibid.).

It is also worth adding that the Code does not permit pre-trial discovery of documents from third parties.

Fee arrangements where lawyers' fees are a percentage of the awarded amount are generally allowed. There is no regulation of third party funding of collective proceedings; however, the courts will seek to establish that the funding method will not hamper the independence of the claimant before declaring the collective action admissible. Hence, a certain degree of protection against abuse may be afforded by the judicial enforcement of the rules on the independence of the claimant (Daly, 2017, p. 33).

Controversially and uniquely, in individual private antitrust enforcement cases, Bulgarian courts have recognised the right of claimants to initiate only follow-on actions for damages, at the same time considering stand-alone actions inadmissible (Petrov, 2017, p. 32-34). If only collective private antitrust enforcement action were filed in Bulgarian courts, it is likely that the courts would resolve the question in the same way.

A recent study by A. Petrov reveals that there is no record of successful collective actions for damages (Petrov, 2017, p. 50). This means that collective actions have so far been filed with the aim to obtain an injunction for the discontinuation of alleged practices. After looking at publicly available decisions on collective redress cases, the author points out that almost all of those cases were initiated by the Commission on Consumer Protection (public authority), or representative consumer organizations in cases of unfair commercial practices. Although studies find that collective redress exists in 
Bulgaria (K. Daly mentions at least 17 cases completed with final rulings; see Daly, 2017, p. 17; Georgiev and Hinov, 2011, p. 47; see also K.J. Cseres, 2015, p. 52), it is indicated that Bulgarian claimants are unlikely to initiate or join class actions (Petrov, 2017, p. 50).

\section{Compensatory collective redress in Lithuania}

The Lithuanian national framework for group actions entered into force on 1 January 2015 and refers to damages claims as one of the admissible types of group claims. However, it is argued in legal literature that rules of the Lithuanian civil procedure codes - both the new one of $2002^{6}$ and the former one of 1964 - provided, already beforehand, for a 'hypothetical' possibility to raise a group action in order to protect the public interest (Juška, 2016, p. 375; Juška, 2015, p. 1; Rodger, 2014, p. 176; see also Mizaras, 2012). Even so, it needs to be taken into account that there were no further provisions specifying the type of claims, legal standing, requirements for pursuing claims and the procedure. Due to this gap, the rules were ineffective as they were unable to produce any practical results.

Group actions are now regulated in Chapter 24-1 (Articles $441^{1}-441^{17}$ ) of the Civil Procedure Code. In general, there is no provision for any specialist court or tribunal to deal only with group actions, and according to Article 4411(4), such proceedings fall within the competence of general (civil) courts, more precisely regional courts (apygardos teismai). ${ }^{7}$ However, while this provision constitutes lex generalis, Article 51(2)(1) of the Lithuanian Competition Act ${ }^{8}$ constitutes lex specialis here, stating an exception to the general rule. The latter stipulates that competition law proceedings concerning damages claims can only be raised before the Vilnius Regional Court, ${ }^{9}$ regardless of whether these are individual or group proceedings.

Article $441^{3}(2)(1)$ of the Code states that a group must comprise at least 20 natural or legal persons. The group is represented by a group representative, previously identified as a member of the group or an association/trade union, if the group action is associated with a legal relationship directly related to their goals and activities, and at least 10 members of the group are members

\footnotetext{
${ }^{6}$ Available in Lithuanian at: http://www.infolex.lt/portal/start_ta.asp?act $=$ doc\&fr $=$ pop\& doc $=77554$.

7 There are five regional courts in Lithuania.

8 Available in Lithuanian at: https://www.e-tar.lt/portal/lt/legalAct/ad961110dd8911e69ae9f $38427 b 46 d d 7$.

9 See also Article 28(4) of the Civil Procedure Code.
} 
of this association/trade union (Article $441^{4}(1)-(2)$ ). However, associations (e.g. consumer associations) are very limited in terms of their ability to finance litigation because of their very small budgets (Juška, 2016, p. 384-385).

The Code provides for compulsory representation by an attorney in group action cases (Article 4414(3)).

The group action must be based on an identical or similar factual background, and must seek to protect, with the same remedies, the same or similar interests of the group members (Article $441^{1}(2)$ ). Furthermore, group redress is designed to be applied only where the group action is a more economical, more effective and more appropriate way to resolve a particular dispute than unitary pieces of litigation (Article 4413(1)(2)of the Code). Before group proceedings, a pre-court dispute resolution procedure must take place (Article $441^{2}$ ).

Article 87(1) of the Code states that if the claimed amount does not exceed EUR 30,000, the court registration fee is set for 3\% of the claimed amount (but not less than EUR 20). Where the claimed amount is between EUR 30,000 and EUR 100,000, the court registration fee is set for EUR 900 plus $2 \%$ of the claimed amount exceeding EUR 30,000. If the claimed amount exceeds EUR 100,000, the court registration fee is calculated by adding EUR 2,300 to $1 \%$ of the claimed amount exceeding EUR 100,000. The court registration fee is capped at EUR 15,000.

If the court allows the group action, it sets a time limit of 60 to 90 days to enlarge the group. Unlike the obligatory announcements concerning an action determined by Bulgarian courts (which came under fire from legal literature), based on the analysis of Article 4418(2) of the Code, it can be found that courts in Lithuania are not competent to make a decision on announcements. It is the group representative who can decide voluntarily on informing potential group members about the action. The group representative may encourage additional group members to join the group through mass media and other means.

Pre-trial or other discovery vis-á-vis defendants and/or third parties, in the form and scope known in common law countries, are not foreseen in Lithuanian rules governing group proceedings.

There are no special provisions on litigation funding in Lithuania. If a case is won, costs are recovered from the unsuccessful party to the level authorised by law. Interestingly, contingency fees are permissible in group actions. However, contingency fees have so far had no impact in Lithuania (Juška, 2016, p. 394). Contingency fees are permissible also in individual actions for the breach of competition law, and there have been up to 10 individual private enforcement cases (both standalone and follow-on cases, no cartel-related private enforcement cases) since 2003 (Mikelènas and Zaščiurinskaitè, 2017, p. 180). Nevertheless, no private antitrust action has been brought under 
a contingency-fee agreement (Juška, 2016, p. 386). Moreover, researchers say that there is no practice regarding group antitrust actions in Lithuania so far (Mikelènas and Zaščiurinskaitė, 2017, p. 199; Juška, 2016, p. 385). Legal literature also states that the only one such case brought on behalf of around 7,000 heat consumers was rejected due to the group plaintiff's failure to comply with pre-court dispute-resolution procedures (Ukmergès rajono savivaldybe v. $U A B$ "Energijos taupymo centras" bei UAB "Miesto energija", decision of the Court of Appeals of Lithuania of 10 July 2015, case No E2-816-157/2015; ${ }^{10}$ see Juška, 2016, p. 385). Injured persons do not seem interested in taking steps to pursue their claims in group proceedings in Lithuania.

\section{Compensatory collective redress in Poland}

In Poland, collective redress is governed by the Act on the Pursuit of Claims in Group Proceedings of 17 December 2009. ${ }^{11}$ The draft of this Act met with harsh criticism during the public consultation process in 2008. Among others, the feedback submitted by the National Council of the Judiciary of Poland was that the proposed provisions were 'underdeveloped' and the language was inconsistent with the Civil Procedure Code. ${ }^{12}$

After over seven years of experience with the use of group actions in Poland, the general belief seems to be that group actions contribute to the resolution of disputes in Poland. The latest official data ${ }^{13}$ shows that altogether 225 group actions were filed in 2010-2016 in Polish courts; none of them, however, has been reported as an antitrust case. In 2011-2016, there were 34 group actions per annum on average. While the number of group actions has been steadily increasing for some time over recent years, it has been gradually decreasing in the past two years. Even though the Act came into effect on 19 July 2010, there were 21 group actions in 2010 alone (less than half a year), 38 in 2011 and 39 group actions in 2012. After a decrease to the lowest level measured in 2013 (22 actions), the 2014 rise to 42 actions was unprecedented. Finally, there were 33 such actions in 2015 and 30 in 2016. However, as the Ministry of Development commented in 2016, 'after around six years of the functioning

10 The case included a claim for unjust enrichment and the award of EUR 3,758,456.9. The decision is available in Lithuanian at: http://eteismai.lt/byla/243816257406610/e2-816-157/2015.

11 Available in Polish at: http://isap.sejm.gov.pl/DetailsServlet?id=WDU20100070044.

12 Available in Polish at: http://qxdzgfn.krs.gov.pl/pl/dzialalnosc/posiedzenia-rady/ posiedzenia-w-2008-r/c,288,09-11-wrzesnia-2008/p,1/1605,opinia-krajowej-rady-sadownictwa-zdnia-10-wrzesnia-2008-r.

13 Available in Polish at: https://isws.ms.gov.pl/pl/baza-statystyczna/opracowania-wieloletnie/. 
of collective redress, one can clearly see practical problems causing that the mechanism cannot be effectively used in accordance with its intended purpose. The best proof of this is the fact that so far none of "big" group cases has been concluded with a final decision, even though some of them were filed in 2010 ' ${ }^{14}$ In 42 cases, the group action was rejected for formal reasons.

As part of the so-called 'Package for creditors', the Ministry proposed to introduce amendments meant to improve the legal framework for group proceedings. The Act Amending Certain Act to Facilitate the Recovery of Debts proposed by the Government was adopted on 7 April 2017 and entered into force on 1 June 2017.

When adopting the legal framework for the collective redress mechanisms in 2009, the Polish legislature opted for an opt-in system. In the 'Package for creditors', published by the Ministry of Development, it was suggested that a discussion is required on the introduction of an opt-out system. Finally however, this proposal was abandoned.

Regional courts as courts of first instance (and not the lower district courts) have competence in cases which proceed as group actions in Poland (Article 3(1) of the Act on the Pursuit of Claims in Group Proceedings). ${ }^{15}$ After the recent changes in Polish law related to the implementation of the Damages Directive, the same courts have competence in individual actions for antitrust damages irrespective of the amount of claim. However, group cases are judged by a panel of three judges (Article 3(2) of the Act).

It is crucial for the application of the mechanism to define its scope in a broad manner. Before the 2017 amendments, the availability of this mechanism for businesses was restricted. As a result, there were only seven business-to-business actions filed in the courts (3.1\% of the total number of group actions) in 20102016. In the case of businesses, unjust enrichment claims and contractual claims were added to Article 1(2) of the Act by the 2017 amendments.

Those injured persons who are looking to come together in a group need to keep in mind that a group must comprise of at least 10 members with claims of the same kind and with the same or similar factual basis thereof (Article 1(1) of the Act). One of the objectives of the 2017 amendments was to stabilize group proceedings; therefore, in the case of group proceedings initiated after their entry into force, proceedings launched as group proceedings shall be continued in this form irrespective of changes to the group, including the reduction of the group below the level of 10 members due to, for example the death of any of its members (added Article 10a of the Act). The characteristics of the group shall not be re-examined after the certification.

14 'Package for creditors', p. 1. Available in Polish at: https://www.mr.gov.pl/media/21040/ Pakiet_wierzycielski.pdf.

15 There are 45 regional courts in Poland. 
A group is required to have a group representative. Unless a representative is an advocate or a legal advisor, he or she needs to be represented by such a professional lawyer. Article 4(2) of the Act states that a member of the group may act as its representative. This provision entitles also regional (municipal) consumer ombudsmen to pursue group actions on behalf of the group. Four years after the Commission's Recommendations, and in spite of the 2017 amendments of the Polish Act, a collective action cannot be filed by an organisation (such as an association that protects consumers), unless the latter is a member of the group. This limitation will need to be revoked to enable the development proposed by the Commission's Recommendation (see also Piszcz, 2015, p. 74).

Beneficially for potential members of a group, the group plaintiff is able to aim for all types of remedies, including declaratory relief, injunctive and/or compensatory redress. The Ministry's analysis proved that, so far, declaratory relief has been the most popular type of remedy claimed in group proceedings. Plaintiffs required courts to make a declaration that the defendant was liable for the infringement. And what might it mean in practice? Group members could, first, settle with the defendant. Second, after the judgment had become final, they could file individual actions aiming at further remedies. Acting individually before courts, just after acting together as a group in group proceedings, multiplies court proceedings instead of reducing them. Before the 2017 amendments, however, provisions on compensatory redress in group proceedings were vague, and it was quite risky to submit claims for compensation. In particular, the concept of the standardization of claims was a weakness of the Act that had to be addressed. In cases concerning monetary relief, the amounts of individual claims, which make up the overall group litigation, needed to be standardised 'taking into account the common circumstances of the case' (Article 2(1) of the Act). Article 2(2) of the Act stipulates that the standardisation can be made in subgroups of at least two members of the overall group. The explicit reference to 'common circumstances of the case' made courts require plaintiff to show more standardization criteria than only the amount of claims of group members. It was argued that standardisation should be a consequence of one kind of harm, or facts common for subgroup members resulting in the similarity of harm. ${ }^{16}$ This, in fact, resulted in the need to take them on a case-by-case basis, which was contrary to the nature of group proceedings. It was therefore essential to improve the relevant provisions so that, when group proceedings are initiated, plaintiffs have real means to get compensation in those proceedings, rather than only in subsequent individual

16 See decision of the Court of Appeals in Cracow of 7 December 2011, I ACz 1235/11, in Polish available at: http://classaction-pl-tests.kkg.pl/pl/case_law/28-postanowienie-sadu-apelacyj nego-w-krakowie-wydzial-i-cywilny-z-dnia-7-grudnia-2011-r/. 
proceedings. The 2017 amendments include, first, the clarification that the standardization of claims means an equalisation of the amounts of claims of group members or subgroup members, but, secondly, also the improvement of the rules regarding declaratory relief.

Different regional courts have reached different levels of efficiency in group proceedings, and in some of them the waiting time for the appointment of the first public hearing is a few months, whereas in others - a dozen or so. However, in most regional courts, the certification phase used to take at least $1.0-1.5$ years after the action was filed. It needs adding that the requirement of holding a public hearing and the appealability of a certification decision contribute to the prolixity of this stage of group proceedings. Deciding on the certification of group proceedings in chambers, introduced by the 2017 amendments (Article 10(1) of the Act), is a move of the Polish legislature meant to reduce the duration of group proceedings. There was also room for improvements so that parties could benefit from more effective appeal procedures; the 2017 amendments have been focused thereon as well.

There were no amendments made to court registration fees regarding group proceedings; whereas the court registration fee for individual proceedings is (as a rule) $5 \%$ of the claim value, the court registration fee for group proceedings is $2 \%$ of the value of the case, not less than PLN 30 (approx. EUR 7) and not more than PLN 100,000 (approx. EUR 23,250). There is no legal aid to assist group members (Article 24(2) of the Act). In the case of non-pecuniary claims, the court registration fee is PLN 600 (approx. EUR 140). If the value of the case cannot be determined initially, a temporary court registration fee is set between PLN 100 (approx. EUR 23) and PLN 10,000 (approx. EUR 2,330).

A deposit of up to $20 \%$ of the claim value represents another burden for the group plaintiff who may be required by the court to secure the costs of the proceedings upon the defendant's request. However, the request process normally delays the first stage of the proceedings by up to one year (Tulibacka, 2016, p. 15). Moreover, before the 2017 amendments, courts had too much discretion over a deposit. After the amendments, the court may order the group plaintiff to pay a deposit only if the defendant renders plausible that the claim is unfounded and that in the case of its dismissal, the reimbursement of the costs of the group proceedings shall be impossible or seriously impeded (Article 8(1) of the Act).

When reforming group proceedings, the legislature took into account also provisions on a way to publicise group actions (Article 11 of the Act). In the case of actions filed before the 2017 amendments, unless all potential group members joined the class already, an announcement published in a popular nationwide newspaper was obligatory; only in particular cases the court could have ordered an announcement to be published in local press. After the 
amendments, a way to publicise a group action should be chosen with a view to its expediency. In particular, the information may be published on the websites of the competent court, on the websites of the parties or their lawyers, as well as in nationwide or local press.

There are clearly no specific rules on funding in the Act. The 'loser pays' principle is applicable to group proceedings; however, costs are only reimbursed in accordance with tariffs (regulations of the Minister of Justice). It needs to be added that rules on lawyers' ethics, applicable in civil proceedings in general, do not permit agreements whereby lawyers' fees are based exclusively on a percentage of the amount recovered. However, in the case of group proceedings, contingency fees of up to $20 \%$ of the awarded amount are available under no-win no-fee agreements, according to Article 5 of the Act (see also Juška, 2016, p. 387-389). However, contingency fees have had a difficult start in Polish group proceedings. It is clear that, in practice, emphasis used to be on group actions for declaratory relief, where contingency fees, naturally, cannot be applied as there is no 'awarded amount'. But even in the case of claims for compensatory redress, lawyers prefer up-front fees. After a period of around seven years of group proceedings in Poland, only a few examples of the application of contingency fees can be found. The very nature of Polish group proceedings is a barrier to an effective use of contingency fees - those proceedings are too risky and long-lasting to make arrangements on success fees dependent on the adjudicated amount of the claim. Taking into account mandatory tariffs for the reimbursement of legal costs, and the fact that group action cases can attract huge total lawyers' up-front fees, it may be added that lawyers' fees come mostly from group members and not from the defendant. However, it can be said that provisions on contingency fees do not appear to be an effective method to address the above concerns.

\section{Compensatory collective redress in Slovenia (draft legislation)}

The Slovenian Government has adopted the text of the draft Act on Collective Actions (Zakon o kolektivnih tožbah) on 15 June 2017, claiming that collective redress mechanisms shall enhance access to justice, guarantee the rights of individuals infringed in mass harm situations, deter potential infringers from unlawful behaviours, and relieve the burden on courts caused by too many individual actions filed in mass harm situations. ${ }^{17}$

17 See http://www.vlada.si/en/media_room/government_press_releases/press_release/article/ government_discusses_the_crisis_management_system_and_the_introduction_of_the_possibility_ of_collective_action_59992/. The draft Act is available in Slovene at: https://crushus-s6.crushus. 
The draft Act concerns collective actions and collective settlements. Article 2 of the draft Act lists a number of claims that may be brought under the Act, which include claims in competition law cases (Article 2(2)(3)). The draft Act provides for the availability of both compensatory and injunctive remedies.

It is proposed that only one of the Slovenian courts will have exclusive jurisdiction to assess collective actions and collective settlements, namely the Regional Court (okrožno sodišce) in Ljubljana (Article 6 of the draft Act). ${ }^{18}$

According to Article 4 of the draft Act, legal standing is given, first, to non-profit legal persons of civil law whose main operational goals are connected with rights being protected in collective proceedings. Secondly, legal standing is given to the state attorney. The court assesses and determines the eligibility (representativeness) of a representative (Article 5 of the draft Act).

Further conditions for bringing a collective action include the requirement that the same claims are being made on behalf of an identifiable group of persons concerning the same, similar or related matters of fact or law, regarding the same mass harm situation. There is also the requirement that legal and factual issues common for the whole group predominate over issues that relate only to individual members of the group. Furthermore, the court shall be more likely to consider an action suitable for collective proceedings where individual actions may be considered less effective than collective redress. To this end, the court shall take into account a range of factors listed in Article 28(5) of the draft Act covering different aspects of the case, such as, for example costs and benefits of the collective proceedings, the size of the group and whether its members have brought any individual actions.

One should also be aware of the crucial role of the court, namely the determination of whether the certified action should move forward as an optout action or an opt-in action (Article 29(2)(4) and Article 30 of the draft Act). However, if at least one of the claims is related to the compensation for non-pecuniary damages, or if at least $10 \%$ of the members of the group claim payments of more than EUR 2,000, only the opt-in scheme may be used (Article 30(2)). The same applies to cross-border cases (Article 30(3)).

Where the calculation of individual damages is not possible, the court shall aggregate damages (Article 40). In such cases, pursuant to Article 43, the

com/www.vlada.si/delo_vlade/gradiva_v_obravnavi/gradivo_v_obravnavi/?tx_govpapers_pi1\%5B single $\% 5 \mathrm{D}=\% 2 \mathrm{FMANDAT} 14 \% 2 \mathrm{FVL} \overline{\mathrm{A} D N A G R A D I V A .} \overline{\mathrm{NSF}} \% 2 \mathrm{~F} 18 \mathrm{a} 6 \mathrm{~b} 9887 \mathrm{c} 33 \mathrm{a} 0 \mathrm{bdc} 12570 \mathrm{e} 5$ 0034eb54\%2F47b75b5194beaddcc125813d0041d04e\%3FOpenDocument\&cHash=d1a788f512b 4b4bdb681b0d42ff3dfb5.

18 There are 11 regional courts in Slovenia. 
court shall appoint a manager of the collective damages responsible for the distribution of damages to injured parties. This role is attributed to a notary public with a seat in the district of the Regional Court of Ljubljana (unless the court considers it justified to appoint a notary public who has a seat outside the district of the Regional Court of Ljubljana).

When certifying the collective action, the court should also consider whether to order a deposit to be paid by the plaintiff in order to secure the defendant's costs of the proceedings and/or whether to order any additional means of dissemination of information about the action, for example, by way of creating an appropriate website (Article 29(3) of the draft Act).

To sum up this part of the considerations, it is worth emphasising the scale of the challenge facing courts in collective cases. A noticeable degree of discretion given to the court can be observed under the Slovenian draft law, compared with other analysed national legal frameworks.

The draft Act also contains a set of provisions which deal with funding and costs of collective proceedings. First, Article 58 contains rules on the estimation of the claim value, which are more beneficial for plaintiffs than general rules. Second, conditions for third party funding of collective redress are provided for (Article 59). Third, identically to other analysed national legal frameworks, the Slovenian draft Act provides for the 'loser pays' principle (Article 60). Fourth, pursuant to Article 61 of the draft Act, lawyers may be incentivised by success fees of up to $30 \%$ of the amount won (in some cases, of up to $15 \%$ ).

The Slovenian proposal has been shaped to positively address a number of points from the Commission's Recommendation. Importantly, the draft Act does not see only the court system as the best vehicle for achieving justice, but it also regulates issues related to collective settlements (referred to in paragraphs $25-28$ of the Commission's Recommendation).

It is now for the Slovenian legislature to say (or not) 'we are happy' with the proposed level of improvements in access to justice. Admittedly, the range of solutions under the same Act (courts' choice between opt-in and opt-out mechanisms), makes the Slovenian 'experimental model' quite unique in Central and Eastern Europe; the remaining CEE countries do not have anything like this. If it is adopted by the Slovenian legislature, it will remain to be seen whether the mixed system will be effective and, if so, whether it will inspire other countries in the region to cause an 'upheaval' of the systems existing in those countries. 


\section{Questions to be addressed by CEE countries}

The findings from Bulgaria, Poland and Lithuania show the complete dominance of individual actions over collective actions in private enforcement of competition law, even though private antitrust enforcement is not very developed in these countries. With only a few CEE countries having (or almost having) developed a legal framework for compensatory collective redress at all, and almost no practice in the field of collective competition law enforcement, the task of creating compensatory collective redress mechanisms as part of private enforcement of competition law in CEE countries does not look as though it has begun to take root. By and large, the key question to be addressed by those seven remaining CEE countries is whether to introduce legal provisions on collective redress mechanisms (including compensatory) for antitrust claims, or to introduce a generic collective action procedure for all civil claims, or to protect the status quo in which they do not have them at all. Next month (August 2017), however, the Commission will close a 12 -week public consultation launched on 22 May 2017 with the aim of collecting evidence on the operation of collective redress arrangements in EU Member States; afterwards, it will prepare a report. ${ }^{19}$ Furthermore, Member States are obliged to communicate to the Commission on an annual basis their statistics on the number of out-of-court and judicial collective redress procedures as well as information about the parties, the subject matter and outcome of the cases; for the first time, they were supposed to do so by 26 July 2016 at the latest. Based on practical experiences reported by the Member States and the participants of the public consultation process, the Commission shall assess the implementation of its Recommendation which, actually, should have been done by 26 July 2017 (see Section 41 sentence 1 of the Commission's Recommendation). This (somewhat belated) assessment is part of a wider debate over whether further measures to consolidate and strengthen the horizontal approach, reflected in the Commission's Recommendation, should be proposed.

Will the Commission adopt a landmark legislative proposal? It is possible that the Commission's Recommendation will be converted into a proposal for a directive. There may be several reasons for this, including the fact that the Commission's Recommendation was not followed by some of the Member States at all. Second, the Commission's Recommendation makes it clear that in order to balance the risks inherent in collective redress mechanisms, certain safeguards against possible abuses are required. Yet according to the report by K. Daly which covers 10 EU Members States including Bulgaria and Poland,

19 http://ec.europa.eu/newsroom/just/item-detail.cfm?item_id=59539. 
these safeguards are being applied by the chosen Member States 'highly unevenly - if at all' (Daly, 2017, p. 66). Almost a year after the Commission's Recommendation, the European Economic and Social Committee (hereinafter, EESC) called on the Commission to propose a directive as quickly as possible; in the opinion of the EESC, only a directive would ensure a solid core of harmonisation, while at the same time giving the Member States enough leeway for accommodating the particularities of their national legal systems. ${ }^{20}$

It may be that the strategies for the future of some CEE countries are only to wait for the next move of the Commission and neither to introduce collective redress systems nor to improve existing ones unless there is a binding EU instrument thereon. So, many question marks surround, in fact, future EU legislation, namely whether it will introduce a binding measure and, therewith, incentives and reasonable safeguards or, to the contrary, mainly obstacles to the development of effective collective redress mechanisms. If the Recommendation is to be followed by the adoption of EU legislation binding on the Member States, this binding legislation should not deviate considerably from the Recommendation without good reasons. Otherwise, some Member States would not be enthusiastic about the new initiative 'rolling back' their earlier efforts, after being involved in the transposition of the principles contained in the Recommendation to their national laws. In particular, the task of balancing in the draft legislation of the different already existing systems (opt-in, opt-out and mixed) will be challenging but rewarding.

As it has been submitted above, in CEE countries where the legal framework for collective actions has emerged, irrespective of whether they remain a significant addition - at least in terms of numbers - to individual actions (Poland) or not (Bulgaria, Lithuania), their use in private enforcement of competition law has been facing insurmountable problems for years. Therefore, the next question is whether the 'law in books' on generic collective redress mechanisms, introduced in a given CEE country, is going to change the practice and give rise to 'law in action' with regard to claims for antitrust damages (see also Cseres, 2015, p. 57). The problems seem to lie, however, not as much in the collective redress mechanisms themselves, as also in barriers to private enforcement of competition law, irrespective of whether competition law is enforced collectively or individually. The above is supported by the fact that even individual actions for damages are not frequent in many EU Member States, including the CEE countries described in this paper, even though public enforcement of competition law exists therein. This status quo prompted the

${ }^{20}$ Point 3.3 of the opinion of the EESC on the Communication from the Commission to the European Parliament, the Council, the European Economic and Social Committee and the Committee of the Regions Towards a European Horizontal Framework for Collective Redress, $\operatorname{COM}(2013) 401$ final, OJ C 170, 05.06.2014, p. 68. 
EU legislature to adopt the Damages Directive, which is projected to have a substantial impact on private enforcement of EU (but in fact also national) competition law after its transposition into national laws. The Directive does not have a key role to play in ensuring that collective redress mechanisms exist in the field of collective competition law enforcement (see Recital 13 sentence 2 of the Preamble to the Directive). Consequently, as comparative research showed, none of the CEE countries has conducted legislative works on a legal framework for collective redress (its introduction or amendments) while working on the implementation of the Directive, save that Slovenia drafted its Act on Collective Actions taking into account the implementing works.

However, it is at the very 'intersection' of the legal framework for private antitrust enforcement and the legal framework for collective redress where certain efficiencies can be generated that affect the exercising of the functions of competition law enforcement. While the basic function of public enforcement of competition law is deterrence from its infringements, the main focus of private enforcement is on compensation complemented by other functions, including (as the case may be) inter alia restitution and/ or deterrence. ${ }^{21}$ May the Damages Directive alone (after its transposition to national laws) be identified as a potential vehicle to achieve a better exercise of the compensatory function of private enforcement of competition law? Certainly, the Directive contains solutions that are capable of facilitating it. A great example here is that the effect of national competition authorities' final infringement decisions on subsequent actions for antitrust damages will be regulated in Member States (Article 9 of the Directive), which shall facilitate follow-on actions for damages. To a considerable extent, this corresponds to paragraph 33 of the Commission's Recommendation. ${ }^{22}$

While pre-trial discovery is not permitted in collective procedures described in this paper, after the implementation of the Directive, proper procedures

${ }^{21}$ However, M. Strand suggests that where public enforcement serves to deter sufficiently from infringements, it is not necessary to design private enforcement mechanisms so that they safeguard the interest of deterrence (Strand, 2017, p. 418-419). However, thriving private enforcement of competition law would play a crucial role and be particularly welcome as able to deter from infringements where public sanctions are too weak to provide a deterrent.

22 'The Member States should ensure that in fields of law where a public authority is empowered to adopt a decision finding that there has been a violation of Union law, collective redress actions should, as a general rule, only start after any proceedings of the public authority, which were launched before commencement of the private action, have been concluded definitively. If the proceedings of the public authority are launched after the commencement of the collective redress action, the court should avoid giving a decision which would conflict with a decision contemplated by the public authority. To that end, the court may stay the collective redress action until the proceedings of the public authority have been concluded'. 
shall be put in place to allow for evidential disclosure in antitrust cases in both individual and collective proceedings (Article 5-8 of the Directive). At the same time, rules of the Directive do not run counter to Recital 15 sentence 3 of the Preamble to the Commission's Recommendation. The latter recommends avoiding - as a general rule - elements such as intrusive pre-trial discovery procedures, which are foreign to the legal traditions of most Member States.

Limitation periods for claims for antitrust damages will be more reasonable and will make it easier for injured parties to bring actions (Article 10 of the Directive). The rules of the Directive thereon are coherent with paragraphs 27 and 34 of the Commission's Recommendation. ${ }^{23}$

The position of plaintiffs claiming antitrust damages shall also be improved due to pro-plaintiff presumptions, courts' powers to estimate the amount of harm, as well as the share of the overcharge which was passed on, and/or alterations to the burden of proof (Article 12-17).

It seems that, as a result, after the implementation of the Directive facilitating private enforcement of competition law, CEE countries will face an at least slowly increasing number of individual private actions for antitrust damages. With better legal tools in place, it is likely that there will be stronger action against infringements from injured persons. However, the key to success is not only to equip courts, ${ }^{24}$ authorities and parties with powers provided for in the Directive. There are, doubtless, many mass harm situations, where harm is dispersed onto a very large number of victims (typically consumers), individual claims are very small and, consequently, individual actions are likely to be rare. There may be a correlation in the use of compensatory collective redress mechanisms and a better exercise of the functions of private enforcement of competition law, including also deterrence, and this may constitute one of the reasons for the introduction of collective redress mechanisms. Appropriate collective procedures should be available to injured parties. However, while there are no 'carrots' for consumers to be incentivised

23 '27. Any limitation period applicable to the claims should be suspended during the period from the moment the parties agree to attempt to resolve the dispute by means of an alternative dispute resolution procedure until at least the moment at which one or both parties expressly withdraw from that alternative dispute resolution procedure.

(...) 34. The Member States should ensure that in the case of follow-on actions, the persons who claim to have been harmed are not prevented from seeking compensation due to the expiry of limitation or prescription periods before the definitive conclusion of the proceedings by the public authority'.

24 Antitrust actions should be brought before designated courts; ideally for collective private enforcement of competition law, these should be the same courts as those competent to adjudicate collective cases, as they, hopefully, shall have experience in the particular challenges of both sets of specific rules. See the example of Poland where both sets of rules are now applied only by regional courts. 
to bring private antitrust claims, it may turn out that even the introduction of legal provisions on collective redress does not lead to its emergence in practice. Existing legal mechanisms do not always provide effective access to justice, which constitutes a part of the right to fair trial. How to make injured parties to engage in compensatory collective redress? This question leads to another: what would be the best procedural scheme for compensatory collective redress? Opt-in, opt-out or a mixed one?

The claimant party should be formed on the basis of the opt-in principle, says paragraph 21 of the Commission's Recommendation. It advocates that the use of an opt-out mechanism should be duly justified by reasons of sound administration of justice. In academe, among others, L. Ervo writes critically about the opt-in principle as a rule, and the opt-out principle as an exception (Ervo, 2016, p. 186 et seq.). She argues that 'the sound administration of justice seems to require opt-out even if the Commission sees the procedural situation the other way around. (...) the very fundamental principles of law and order as well as public peace, are strong arguments for opt-out. It is only by opting out that the conflict will be resolved as a whole and without any uncertainties in the future. It is in that way and that way alone that public peace, and law and order can be achieved' (ibid., p. 197). S.O. Pais writes that opt-out group actions seem to be most useful where individual claims are difficult to prove or when the value of such claims is too low to motivate consumers to participate in proceedings (Pais and Piszcz, 2014, p. 214). K. Daly disagrees, particularly as the opt-out principle 'robs group members of their legal autonomy, because individuals can become participants in litigation that they do not support - or that they outright oppose' (Daly, 2017, p. 39). He adds that in opt-in proceedings, the groups tend to include only claimants who are personally and actively interested in pursuing their rights; he is concerned about opt-out cases involving groups of mostly apathetic claimants (ibid.). Unlike him, L. Ervo rightly observes that this means protecting wrongdoers rather than an effective tool to realise substantive law correctly and when needed (Ervo, 2016, p. 198).

While several of the researched CEE countries use the opt-in principle recommended by the Commission as part of their compensatory collective redress systems, the prospect of Slovenia remains some way off. However, as noted above, the existence of a legal framework for compensatory collective redress based on the opt-in principle has not given rise to collective actions for antitrust damages in the researched CEE countries. Its introduction may, then, do little to increase its application in practice. Opt-in systems existing in CEE countries are characterised by low rates of take-up right and procedural delays. The Slovenian idea of a mixed system seems to be a truly crucial and important part of the development of private antitrust enforcement, as 
it combines reasons of sound administration of justice and safeguards against possible abuses. Unless courts abuse their discretionary powers with regard to the choice of a system, the proposed solution shall not lead to inadvertent outcomes. Instead, it may boost the application of collective redress, also in antitrust cases. We now have to wait for the adoption of the proposed legal provisions and a 'pilot run' of the mixed scheme, which may constitute an inspiration for other CEE countries.

Insights from these considerations can form the basis for another question regarding the legal standing to bring a collective redress action. The Commission's Recommendation is designed to cover aspects of both group actions and representative actions. ${ }^{25}$ It may well be that a broad legal standing would be beneficial to access to justice. Collective claims for damages should be capable of being brought by a wide range of parties. First, national legal frameworks should provide for group actions (which is not going to be the case in Slovenia). The threshold requirement of standing should not be imposed by legislation. Polish and Lithuanian solutions requiring - respectively - at least 10 or 20 members of a group seem to run counter to the Commission's Recommendation referring literally to 'two or more natural or legal persons'. ${ }^{26}$ On the other hand, however, the recognition of only two persons as a group by legislation may be counterproductive, as collective redress mechanisms do not seem designed for groups comprising two members. Unless the EU changes its approach ('two or more natural or legal persons'), the adequacy of a group in terms of the number of its members should depend on a court decision (see Bulgarian and Slovenian solutions). It should be observed, however, that systems where the size of the group based on a quantitative normative evaluation is not the only condition for the certification of a group are likely lacking legal certainty for claimants. Implementing safeguards against speculative or unmeritorious claims is an issue that some believe can be resolved by a requirement that the court considers that a collective redress

25 E. Silvestri says, however, that in the Commission's Recommendation 'standing to sue is granted only to "representative entities" identified in advance by Member States or to public authorities' (see Silvestri, 2013, p. 49). Obviously, the 'body' of the Commission's Recommendation with respect to legal standing contains - in Chapter III ('Principles common to injunctive and compensatory collective redress') - only the subchapter 'Standing to bring a representative action'. But at the same time, recital 17 of the Preamble to the Commission's Recommendation gives an insight into the broader range of available collective actions: 'Legal standing to bring a collective action in the Member States depends on the type of collective redress mechanism. In certain types of collective actions such as group actions (...), the issue of standing is more straightforward than in the context of representative actions, where accordingly the issue of legal standing should be clarified'. See also para. 10 sentence 2 .

${ }^{26}$ Para. 3(a), (b) and (d). 
action is the best way of bringing the case and a strong process of judicial certification (Nikpay and Taylor, 2014, p. 285). ${ }^{27}$

Second, national legal frameworks should also provide for representative actions: by organisations (not available in Poland) and, in addition rather than as an alternative, by public authorities (for example, state attorneys in Slovenia). Even though the latter type of collective actions may be considered to have somewhat of a regulatory nature, such 'private-public' diversification is important in order to minimise the risk that where there are opportunities for compensatory collective redress, they are not missed by the passivity of the empowered bodies. Paragraph 4 of the Recommendation recognises the minimum conditions of eligibility of representative entities. They were welcomed by the EESC which, however, considered it excessive and unacceptable for these conditions to include sufficient financial and personnel resources as well as legal expertise. Such requirements would raise the question of what standards will actually be used to decide on this matter in individual cases, rather than be able to prevent improper litigation.

Last but not least, the costs and funding of collective litigation have certainly an effect on the discussed phenomenon. The above research indicating features of national legal frameworks focuses on both: solutions that seem to have the potential to encourage collective actions (although perceived as risky from the perspective of potential abusive litigation), and potentially limiting ones. In the case of the former, the issue of contingency fees must be referred to. Experience from non-antitrust collective proceedings conducted in Poland shatters the illusion of the seemingly compelling attractiveness of contingency fees (resulting in abusive collective litigation). In spite of their availability, they have been rarely agreed upon between lawyers and injured parties. In the case of the second type of solutions, examples from Bulgaria may demonstrate the importance of the level of court registration fees, as well as the existence of cheap flexible ways of publicising information about collective actions. Furthermore, provisions on a deposit to secure the defendant's procedural costs must be reasonable. In collective proceedings, procedural cost savings

27 Echoing this, it should be noted that also the condition requiring a group representative to be represented by a professional lawyer (see Lithuanian and Polish solutions) may be considered a kind of safeguard (as one of the requirements related to standing). As to more safeguards, the researched CEE countries have the 'loser pays principle' seen in much of Europe and none of them recognises punitive damages. Having relatively stringent certification standards, they (except for Poland) gain no competitive advantage compared to other EU Member States. While Slovenia has prepared its draft legislation providing for a mixed system of collective redress, the fact remains that opt-in mechanisms are favoured in the region. Yet, as this article notes, contingency fees face an uncertain future not only due to the criticism from the Commission's Recommendation but also because they are not applied in practice. 
should be achieved, and not the opposite. The conducted research leads to the conclusion that, out of those scrutinised, only Slovenian provisions (if adopted) regulate funding of collective redress in a comprehensive way. In Slovenia, moreover, funding shall be regulated in compliance with the Commission's Recommendation. In Lithuania and Poland, legislatures eventually ignored the Commission's Recommendation and allow for self-financed actions as well as actions funded by third parties without scrutiny by the court. They will need to tackle funding issues if the EU keeps emphasising them in its next piece of legislation; however, it remains to be seen what results (in any) the regulation of funding will produce for the application of collective redress mechanisms.

\section{Is there strength in numbers? Conclusion}

Is there strength in numbers? There may well be in the case of private enforcement of competition law, if only the legal framework in place includes a balanced, proportionate and effective scheme for compensatory collective redress. The realisation must not be ignored that infringements of competition law may result in harm suffered by large numbers of individuals, including indirect purchasers (or suppliers). They need to be provided with actual opportunities of access to justice. The debate on the implementation of the Damages Directive is largely over. However, the expected assessment being prepared recently by the Commission (will it reassert its position taken in 2013?) shall stoke up the debate about developments of collective redress mechanisms in the Member States.

What can be said about the researched CEE developments in general? The scrutiny of their legal frameworks leads to the conclusion that as a region, CEE has progressed substantially over the last decade in the field of 'law in books' on compensatory collective redress. Initially, only Bulgaria had a developed legal framework for compensatory collective redress that could be applied also to antitrust actions. Subsequent pieces of legislation on collective redress adopted in the region (Poland and Lithuania) focused also on compensatory redress, although they differed widely in details both from each other as well as from what was to come later in Slovenian draft legislation.

Most of the main elements for effective compensatory collective redress are already in place in the researched CEE countries. Both consumers and businesses are able to recover damages. Claims for damages can be pursued both on a stand-alone basis (save that Bulgarian courts have not admitted them in individual antitrust proceedings) as well as in follow-on cases brought 
after public enforcement decisions. The 'loser pays' principle is applicable with regard to collective proceedings. After the implementation of the Damages Directive, rules will be in place on the disclosure of evidence that shall not threaten to leave claimants without access to evidence.

There is a need, however, to introduce generic (and not sectorial) collective redress systems where they are absent or add the right to pursue antitrust claims to existing systems (Croatia, Hungary) and improve the already shaped systems of collective redress, as there was almost no practice before with regard to collective private enforcement of competition law. In essence, the problem of an opt-in, opt-out or mixed scheme of compensatory collective redress should be rethought. It is instructive that Slovenia opted for a mixed system during its recent legislative works. Provisions on legal standing should be changed so that collective actions could be initiated by a wider range of parties. Solutions on litigation costs and funding should be improved. Last but not least, there is a need for more 'consensual' approach, which Slovenia may be praised for. In CEE countries, low rates of settlements remain problematic. Certainly, encouraging collective settlements of cases without going to the courts is something CEE countries should be doing more of.

\section{Literature}

Blažo, O. (2017). Slovakia. In: A. Piszcz (ed.), Implementation of the EU Damages Directive in Central and Eastern European Countries. Warsaw: University of Warsaw, Faculty of Management Press.

Butorac Malnar, V. (2017). Croatia. In: A. Piszcz (ed.), Implementation of the EU Damages Directive in Central and Eastern European Countries. Warsaw: University of Warsaw, Faculty of Management Press.

Cseres, K.J. (2015). Harmonising Private Enforcement of Competition Law in Central and Eastern Europe: The Effectiveness of Legal Transplants Through Consumer Collective Actions. Yearbook of Antitrust and Regulatory Studies, 8(12), 33-59.

Daly, K. (2017). The Growth of Collective Redress in the EU: A Survey of Developments in 10 Member States. Washington: U.S. Chamber Institute for Legal Reform.

Ervo, L. (2016). "Opt-in is out and opt-out is in": Dimensions based on Nordic options and the commission's recommendation. In: B. Hess, M. Bergström, E. Storskrubb (eds), EU civil justice: Current issues and future outlook. Oxford-Portland: Hart Publishing.

Gac, M. (2016). Group litigation as an instrument of competition law enforcement-analysis based on European, French and Polish experience. Doctoral thesis prepared in the form of international cooperation between the Jagiellonian University and the University of Toulouse.

Georgiev, R. and Hinov, H. (2011). Bulgaria. In: The International Comparative Legal Guide to Class \& Group Actions 2011: A practical cross-border insight into class and group actions. Global Legal Group. 
Juška, Z. (2015). Country Report: Class Actions in Lithuania. In: Global Class Actions Exchange. Stanford: Stanford Law School. Retrieved from: http://globalclassactions. stanford.edu/content/class-actions-lithuania.

Juška, Z. (2016). The Impact of Contingency Fees on Collective Antitrust Actions: Experiments from Lithuania and Poland. Review of Central and East European Law, 41, 368-395.

Mikelėnas, V. and Zaščiurinskaitė, R. (2017). Lithuania. In: A. Piszcz (ed.), Implementation of the EU Damages Directive in Central and Eastern European Countries. Warsaw: University of Warsaw, Faculty of Management Press.

Mircea, V. (2017). Romania. In: A. Piszcz (ed.), Implementation of the EU Damages Directive in Central and Eastern European Countries. Warsaw: University of Warsaw, Faculty of Management Press.

Miskolczi Bodnár, P. (2017). Hungary. In: A. Piszcz (ed.), Implementation of the EU Damages Directive in Central and Eastern European Countries. Warsaw: University of Warsaw, Faculty of Management Press.

Mizaras, V. (2012). Lithuania. In: Focus on collective redress, https://www.collectiveredress. org/collective-redress/member-states. London: British Institute of International and Comparative Law.

Nikpay, A. and Taylor, D. (2014). The New UK Competition Regime: Radically Different or More of the Same? Journal of European Competition Law \& Practice, 5(5), 278-286.

Pais, S.O. and Piszcz, A. (2014). Package on Actions for Damages Based on Breaches of EU Competition Rules: Can One Size Fit All? Yearbook of Antitrust and Regulatory Studies, 7(10), 209-234.

Pärn-Lee, E. (2017). Estonia. In: A. Piszcz (ed.), Implementation of the EU Damages Directive in Central and Eastern European Countries. Warsaw: University of Warsaw, Faculty of Management Press.

Petr, M. (2017). Czech Republic. In: A. Piszcz (ed.), Implementation of the EU Damages Directive in Central and Eastern European Countries. Warsaw: University of Warsaw, Faculty of Management Press.

Petrov, A. (2017). Bulgaria. In: A. Piszcz (ed.), Implementation of the EU Damages Directive in Central and Eastern European Countries. Warsaw: University of Warsaw, Faculty of Management Press.

Peyer, S. (2012). Private antitrust litigation in Germany from 2005 to 2007: Empirical evidence. Journal of Competition Law \& Economics, 8(2), 331-359.

Piszcz, A. (2014). "Class Actions" in the Court Culture of Eastern Europe. In: L. Ervo, A. Nylund (eds), The Future of Civil Litigation - Access to Courts and Court Connected mediation in the Nordic Countries. Cham: Springer International Publishing Switzerland.

Piszcz, A. (2015). A few remarks on standing to bring a collective redress action. In: A. Budnik (ed.), Locus standi across legal cultures. Biatystok Volumes on Law \& Culture 3. Białystok: Temida2.

Piszcz, A. and Wolski, D. (2017). Poland. In: A. Piszcz (ed.), Implementation of the EU Damages Directive in Central and Eastern European Countries. Warsaw: University of Warsaw, Faculty of Management Press.

Rodger, B. (2014). Collective Redress Mechanisms and Consumer Case-Law. In: B. Rodger (ed.), Competition Law Comparative Private Enforcement and Collective Redress across the EU. Alphen aan den Rijn: Wolters Kluwer. 
Silvestri, E. (2013). Towards a Common Framework of Collective Redress in Europe? An Update on the Latest Initiatives of the European Commission. Russian Law Journal, I(1), 46-56.

Stoica, S., Ion, M. and Bercaru, L. (2015). Romania. In: I. Knable Gotts (ed.), The Private Competition Enforcement Review. London: Law Business Research Ltd.

Strand, M. (2017). The Passing-On Problem in Damages and Restitution Under EU Law. Cheltenham-Northampton: Edward Elgar Publishing.

Tulibacka, M. (2016). Class Actions in Poland 2016: Lingering problems and reform proposals. Report for the Conference 'Empirical Evidence on Collective Redress in Europe', at the University of Oxford, 12-13 December 2016 Retrieved from: https:// www.law.ox.ac.uk/sites/files/oxlaw/poland_-_tulibacka.docx.

Vlahek, A. (2016). Challenges of Private Enforcement of Antitrust in Slovenia. In: M. Kovač, A.-S. Vandenberghe (eds), Economic Evidence in EU Competition Law. Cambridge: Intersentia.

Vlahek, A. (2016a). Novosti na področju odškodninskih tožb zaradi kršitev evropskega antitrusta. Pravnik, 71(133), 547-590.

Vlahek, A. and Podobnik, K. (2017). Slovenia. In: A. Piszcz (ed.), Implementation of the EU Damages Directive in Central and Eastern European Countries. Warsaw: University of Warsaw, Faculty of Management Press. 